\title{
GAMBARAN FAKTOR-FAKTOR YANG MEMPENGARUHI TERKENDALINYA KADAR GULA DARAH PADA PASIEN DIABETES MELLITUS DI PUSKESMAS PAKIS SURABAYA
}

\author{
Erika Untari Dewi \\ AKPER William Booth Jln. Cimanuk No.20 Surabaya Email: untarierika@yahoo.id
}

\begin{abstract}
ABSTRAK
Keberhasilan pengobatan pada pasien Diabetes Mellitus salah satunya dilihat dari terkendalinya kadar gula darah. Terkendalinya kadar gula darah ini dipengaruhi oleh faktor diit, aktivitas fisik, kepatuhan minum obat dan pengetahuan. Keterlibatan faktor-faktor ini dapat mempengaruhi kondisi kesehatan. Pasien Diabetes Mellitus sering datang ke Puskesmas dan dilakukan pemeriksaan gula darah banyak yang gula darahnya naik atau tidak terkendali. Tujuan dari penelitian ini adalah untuk mengidentifikasi faktor-faktor yang mempengaruhi terkendalinya kadar gula darah pada pasien Diabetes Mellitus. Desain yang digunakan pada penelitian ini deskriptif korelasi. Dalam penelitian ini menggunakan variabel independen dan dependen. Populasi dari Penelitian ini adalah seluruh pasien Diabetes Mellitus di Puskesmas Pakis. Sampel yang digunakan 40 orang dengan menggunakan teknik consecutive sampling. Pengambilan data dengan kuisioner. Data diperoleh dari hasil kuisoner, data yang terkumpul ditabulasi dengan tabel dan dikonfirmasikan dalam bentuk tabel. Dari hasil penelitian ini didapatkan hasil faktor diit tidak mempengaruhi terkendalinya kadar gula darah, faktor aktivitas fisik mempengaruhi terkendalinya kadar gula darah, faktor kepatuhan minum obat tidak mempengaruhi terkendalinya kadar gula darah, faktor pengetahuan mempengaruhi terkendalinya kadar gula darah. Hal ini menunjukkan bahwa faktor aktivitas fisik dan faktor pengetahuan mempengaruhi terkendalinya kadar gula darah.
\end{abstract}

Kata Kunci : terkendalinya kadar gula darah, pasien diabetes mellitus.

\section{ABSTRACT}

The success of treatment in patients with Diabetes Mellitus seen one of uncontrolled blood sugar levels. Controlled blood sugar levels are influenced by dietary factors, physical activity, medication adherence and knowledge. The involvement of these factors can affect the health condition. Diabetes Mellitus Patients often come to the health center and conducted many blood sugar checks blood sugar rises or uncontrolled. The purpose of this study was to identify factors that affect the controlled blood sugar levels in patients with Diabetes Mellitus. The design used in this study descriptive correlation. In this study using independent and dependent variables. The population of this study were all patients with Diabetes Mellitus in Pakis health center. The sample used 40 people using consecutive sampling technique. Data collection was by questionnaire. Data obtained from the questionnaire, the data were collected and tabulated with confirmed tables in tabular form. From the results of this study showed no dietary factors affect uncontrolled blood sugar levels, factors influencing physical activity controlled blood sugar levels, medication adherence factor does not affect uncontrolled blood sugar levels, knowledge of factors affecting uncontrolled blood sugar levels. This shows that the factor of physical activity and factors influencing knowledge controlled blood sugar levels.

Keywords: controlled blood sugar levels, patients with diabetes mellitus

\section{Pendahuluan}

Saat ini di Indonesia mengalami percepatan peningkatan penderita Diabetes Mellitus, hal ini terutama diakibatkan oleh perkembangan pola makan yang salah. Menurut WHO, ( 1994 ) berbagai masyarakat telah membuktikan bahwa peningkatan masukan makanan berlemak jenuh serta penurunan makanan berserat dapat berakibat menurunnya kesensitifan insulin dan ketidaknormalan toleransi glukosa. Diabetes 
mellitus adalah suatu kumpulan gejala yang timbul pada seseorang yang disebabkan oleh karena adanya peningkatan kadar glukosa darah akibat kekurangan insulin baik absolut maupun relatif. ( Soegondo, 1995 ). Salah satu hal yang terpenting bagi penderita Diabetes Mellitus adalah pengendalian kadar gula darah, untuk itu pasien perlu memahami mengenai hal-hal yang mempengaruhi pengendalian kadar gula darah. Pengendalian kadar gula darah adalah menjaga kadar gula darah dalam kisaran normal seperti bukan pasien DM, sehingga dapat terhindar dari hiperglikemia atau hipoglikemia (Soegondo, 1996). Ada beberapa yang bisa mempengaruhi pengendalian meliputi faktor diit, aktifitas fisik, kepatuhan minum obat dan pengetahuan ( Soegondo, 1995 ). Dilihat dari kenyataan dilapangan bahwa penderita Diabetes Mellitus sering datang ke Puskesmas dan dilakukan pemeriksaan gula darah banyak penderita Diabetes Mellitus yang gula darahnya naik atau tidak terkendali, ada yang kadar gula darahnya naik hingga $400 \mathrm{mg} / \mathrm{dL}$.

Insiden Diabetes Mellitus mengalami peningkatan dan di indonesia menempati urutan ke-4 menurut Badan Kesehatan Dunia ( WHO ). Prevalensi Diabetes Mellitus dari jumlah penduduk di indonesia $\pm 1,5 \%$ tiap tahun. Sehingga diperkirakan bahwa terdapat minimal 30.000 penderita Diabetes Mellitus di Surabaya, 300.000 di Jawa Timur dan 2.500.000 di seluruh Indonesia. Tahun 1994 terdapat 110,4 juta penderita Diabetes Mellitus di dunia ( Tjokroprawiro, 2003 ). Tahun 2000 di Indonesia diperkirakan terdapat 4 juta dan 175,4 juta penderita Diabetes Mellitus diseluruh dunia. Berdasarkan studi pendahuluan yang dilakukan oleh penulis di Puskesmas Pakis Surabaya didapatkan 11 dari 20 orang yang menderita penyakit Diabetes Mellitus yang datang ke Puskesmas dan dilakukan pemeriksaan gula darah didapatkan gula darahnya naik atau tidak terkendali, ada yang kadar gula darahnya naik hingga $400 \mathrm{mg} / \mathrm{dL}$. Saat ditanya 11 orang tahu tentang diet untuk Diabetes Mellitus tetapi mereka ada yang bosan, ingin makan makanan yang enak, ada yang mengatakan masih suka ngemil, jarang melakukan aktivitas fisik, teratur minum obat dan memiliki pengetahuan yang cukup tentang Diabetes Mellitus, sedangkan 9 orang mengatakan sudah biasa dengan diet yang diberikan, selalu melakukan aktivitas fisik, teratur minum obat dan memiliki pengetahuan yang baik tentang Diabetes Mellitus sehingga mereka tidak menganggap ini menjadi beban tapi demi kesembuhan mereka.

Faktor-faktor yang mempengaruhi pengendalian yaitu diit, aktifitas fisik, kepatuhan minum obat dan pengetahuan. Apabila tidak menjalankan pengendalian dengan baik maka akan terjadi penurunan dan peningkatan kadar gula darah yang tidak stabil, selain itu dampak yang lebih parah bisa terjadi shock hipoglikemi suatu keadaan dimana kadar gula darah dibawah $60 \mathrm{mg} / \mathrm{d}$ atau hiperglikemi kondisi gula darah yang tinggi. Atau bisa juga sampai terjadi kematian dampak yang mengakibatkan diabetes mellitus bisa terjadi gagal ginjal kronik sehingga ginjal bekerja keras untuk memproduksi urine yang keluar terus menerus. Ketidak patuhan Diabetes Mellitus terhadap pengendalian dapat berdampak negative terhadap kesehatannya. Jika kadar gula darah tidak terkontrol, komplikasikomplikasi diabetes mellitus yang timbul misalnya pada mata, jantung, saraf dan dapat terjadi komplikasi yang akut seperti hipoglikemi dan ketoasidosis diabetikum ( KAD ) dimana jika tidak segera ditangani komplikasi tersebut dapat membahayakan klien.

Melihat permasalahan tersebut diatas maka yang bisa dilakukan untuk memotivasi penderita diabetes mellitus dalam menjalankan pengendalian kadar gula darah dengan baik adalah mengatur diit setiap penderita sesuai dengan prinsip $3 \mathrm{~J}$ yaitu jumlah makanan, jenis dan jadwal makan. Menganjurkan penderita untuk aktifitas fisik sesudah makan. Menyarankan pasien untuk minum obat secara teratur. Memberikan suatu informasi baik melalui komunikasi, edukasi atau penyuluhan kesehatan ( KIE ) di Puskesmas atau institusi kesehatan dengan pemberian leaflet dan brosur, selain juga pendekatan yang dilakukan oleh petugas kesehatan kepada penderita diabetes mellitus sangat penting melalui kunjungan rumah. Memberikan pembelajaran kepada penderita agar mau melakukan tindakantindakan untuk memelihara atau mengatasi masalah-masalah dan meningkatkan kesehatannya. Guna membantu pengendalian kadar gula darah oleh karena itu peneliti tertarik dengan tujuan untuk mengetahui sejauh mana gambaran faktor-faktor yang pempengaruhi terkendalinya kadar gula darah pada pasien Diabetes Mellitus di Puskesmas Pakis Surabaya. Adanya efek yang membahayakan tersebut maka diperlukan adanya strategi pelaksanaan, dokter dan ahli gizi serta tindakan mandiri perawat seperti memantau kadar gula darah, motivasi 
klien untuk memantau kadar gula darah dan memberikan penyuluhan tentang pentingnya memantau kadar gula darah. Dengan diberikannya penyuluhan diharapkan klien dapat mengetahui cara pengendalian kadar gula darah dan dapat menghindari peningkatan kadar gula darah dengan demikian dapat menurunkan kadar gula darah dan juga menghindari timbulnya komplikasi untuk klien dianjurkan untuk rutin kontrol dan mengikuti olahraga diabetes dan pemberian penyuluhan keluarga agar keluarga turut mendukung program pemantauan kadar gula darah penderita.

\section{Metode}

Berdasarkan tujuan penelitian, desain penelitian yang digunakan adalah desain deskriptif korelasi dimana desain penelitian yang digunakan bertujuan mendeskripsikan atau memaparkan peristiwa-peristiwa yang penting pada masa kini ( Nursalam, 2003 ). Tujuan penelitian adalah untuk menggambarkan Faktor-faktor yang mempengaruhi terkendalinya kadar gula darah pada pasien Diabetes Mellitus di Puskesmas Pakis Surabaya. Variabel independent penelitian ini adalah faktor yang mempengaruhi yaitu diit, aktivitas fisik, kepatuhan minum obat dan pengetahuan. Variabel dependent pada penelitian ini adalah kadar gula darah

Populasi dalam penelitian ini adalah seluruh penderita Diabetes Mellitus yang periksa ke Puskesmas Pakis Surabaya berjumlah 40 orang. Teknik sampling yang digunakan dalam penelitian ini adalah "Total Sampling" yaitu teknik penetapan sampel dengan cara memilih sampel dengan mengambil semua populasi yang ada. Instrumen yang digunakan dalam penelitian ini adalah kuisioner.

Analisa data untuk diit dilakukan dengan cara memberikan pertanyaan, jika jawaban tidak pernah: 1, jarang: 2, kadang-kadang: 3, sering: 4 , selalu: 5. Analisa data Aktivitas fisik dilakukan dengan cara memberikan pertanyaan, jika jawaban pernah: 1, jarang: 2, kadang-kadang: 3, sering: 4, selalu: 5. Analisa data Kepatuhan minum obat dilakukan dengan cara memberikan pertanyaan, jika jawaban pernah: 1, jarang: 2 , kadang-kadang: 3, sering: 4, selalu: 5. Analisa data Pengetahuan dilakukan dengan cara memberikan 10 pertanyaan, kemudian menjumlah nilai yang didapat dengan rumus $\mathrm{F} / \mathrm{N}$ $\mathrm{X} 100 \%$

$\mathrm{P}=$ Prosentase

$\mathrm{F}=$ Jumlah nilai yang didapat

$\mathrm{N}=$ Jumlah nilai maksimal
Kriteria penilaian :

Untuk diit 25-50: Patuh

$<25$ : Tidak patuh

Untuk aktivitas fisik

25-50 : Melakukan

$<25$ : Tidak melakukan

Untuk kepatuhan minum obat

25-50: Teratur

$<25$ : Tidak teratur

Pengetahuan

Baik: $80-100 \%$

Cukup: $60-79 \%$

Kurang: $<60 \%$

Hasil

Tabel 1. Karakteristik responden berdasarkan usia di Puskesmas Pakis Surabaya Juni 2014

\begin{tabular}{llll}
\hline No. & Usia & Jumlah & Prosentase \\
\hline 1 & $\leq 20$ tahun & - & $0 \%$ \\
2 & $\begin{array}{l}21-40 \\
\text { tahun }\end{array}$ & - & $0 \%$ \\
3 & $\begin{array}{l}41-60 \\
\text { tahun }\end{array}$ & 30 & $75 \%$ \\
4 & $>$ & 10 & $25 \%$ \\
& $\begin{array}{l}\text { tahun } \\
\text { Jumlah }\end{array}$ & 40 & $100 \%$ \\
\hline
\end{tabular}

Tabel 2. Karakteristik responden berdasarkan jenis kelamin di Puskesmas Pakis Surabaya Juni 2014

\begin{tabular}{llll}
\hline No. & Jenis Kelamin & Jumlah & Prosentase \\
\hline 1 & Laki-laki & 8 & $20 \%$ \\
2 & Perempuan & 32 & $80 \%$ \\
& Jumlah & 40 & $100 \%$ \\
\hline
\end{tabular}

Tabel 3 Karakteristik responden berdasarkan Pendidikan di Puskesmas Pakis Surabaya Juni 2014

\begin{tabular}{llll}
\hline No. & Pendidikan & Jumlah & Prosentase \\
\hline 1. & SD & 15 & $37,5 \%$ \\
2. & SMP & 17 & $42,5 \%$ \\
3. & SMA & 8 & $20 \%$ \\
4. & Perguruan & - & $0 \%$ \\
& Tinggi & & \\
& Jumlah & 40 & $100 \%$ \\
\hline
\end{tabular}

Tabel 4 Karakteristik responden berdasarkan pekerjaan di Puskesmas Pakis Surabaya Juni 2014

No. Pekerjaan Jumlah Prosentase




\begin{tabular}{llll}
\hline 1. & PNS & 1 & $2,5 \%$ \\
2. & Swasta & 2 & $5 \%$ \\
3. & Wiraswasta & 6 & $15 \%$ \\
4. & IRT & 30 & $75 \%$ \\
5. & Tidak bekerja & 1 & $2,5 \%$ \\
& Jumlah & 40 & $100 \%$ \\
\hline
\end{tabular}

Tabel 5 Karakteristik responden berdasarkan faktor diit di Puskesmas Pakis Surabaya Juni 2014

\begin{tabular}{llll}
\hline No. & Faktor Diit & Jumlah & Prosentase \\
\hline 1. & Patuh & 28 & $70 \%$ \\
2. & Tidak Patuh & 12 & $30 \%$ \\
& Jumlah & 40 & $100 \%$ \\
\hline
\end{tabular}

Tabel 6 Karakteristik responden berdasarkan faktor aktivitas fisik di Puskesmas Pakis Surabaya Juni 2014

\begin{tabular}{llll}
\hline No. & $\begin{array}{l}\text { Faktor } \\
\text { Aktivitas Fisik }\end{array}$ & Jumlah & Prosentase \\
\hline 1. & Melakukan & 33 & $82,5 \%$ \\
2. & Tidak & 7 & $17,5 \%$ \\
& $\begin{array}{l}\text { Melakukan } \\
\text { Jumlah }\end{array}$ & 40 & $100 \%$ \\
\hline
\end{tabular}

Tabel 7 Karakteristik responden berdasarkan faktor kepatuhan minum obat di Puskesmas Pakis Surabaya Juni 2014

\begin{tabular}{|c|c|c|c|}
\hline No. & $\begin{array}{l}\text { Faktor } \\
\text { Kepatuhan } \\
\text { Minum Obat }\end{array}$ & Jumlah & Prosentase \\
\hline 1. & Teratur & 37 & $92,5 \%$ \\
\hline \multirow[t]{2}{*}{2.} & Tidak Teratur & 3 & $7,5 \%$ \\
\hline & Jumlah & 40 & $100 \%$ \\
\hline
\end{tabular}

Tabel 8 Karakteristik responden berdasarkan faktor pengetahuan di Puskesmas Pakis Surabaya Juni 2014

\begin{tabular}{llll}
\hline No. & Faktor & Jumlah & Prosentase \\
& Pengetahuan & & \\
\hline 1. & Baik & 13 & $32,5 \%$ \\
2. & Cukup & 15 & $37,5 \%$ \\
3. & Kurang & 12 & $30 \%$ \\
& Jumlah & 40 & $100 \%$ \\
\hline
\end{tabular}

Tabel 9 Karakteristik responden berdasarkan terkendalinya kadar gula darah di Puskesmas Pakis Surabaya Juni 2014

\begin{tabular}{|c|c|c|c|c|}
\hline \multirow[t]{2}{*}{ No. } & \multicolumn{2}{|c|}{ Terkendalinya } & \multirow[t]{2}{*}{ Jumlah } & \multirow[t]{2}{*}{ Prosentase } \\
\hline & $\begin{array}{l}\text { Kadar } \\
\text { Darah }\end{array}$ & Gula & & \\
\hline 1 & Baik & & 5 & $12,5 \%$ \\
\hline 2 & Sedang & & 5 & $12,5 \%$ \\
\hline 3 & Buruk & & 30 & $75 \%$ \\
\hline & Jumlah & & 40 & $100 \%$ \\
\hline
\end{tabular}

Tabel 10 Tabulasi silang faktor diit berdasarkan patuh atau tidak patuh di Puskesmas Pakis Surabaya Juni 2014

\begin{tabular}{|c|c|c|c|c|c|}
\hline Qiit & Diit & & & & \\
\hline \multirow[b]{2}{*}{$\begin{array}{l}\text { I erken } \\
\text { dali }\end{array}$} & \multicolumn{2}{|l|}{ Patuh } & \multicolumn{2}{|c|}{ Tidak Patuh } & \multirow{2}{*}{$\begin{array}{l}\text { Tot } \\
\text { al }\end{array}$} \\
\hline & $\begin{array}{l}\text { Juml } \\
\text { ah }\end{array}$ & $\begin{array}{l}\text { Prosent } \\
\text { ase }\end{array}$ & $\begin{array}{l}\text { Juml } \\
\text { ah }\end{array}$ & $\begin{array}{l}\text { Prosent } \\
\text { ase }\end{array}$ & \\
\hline Baik & 3 & $60 \%$ & 2 & $40 \%$ & 5 \\
\hline Sedang & 4 & $80 \%$ & 1 & $20 \%$ & 5 \\
\hline Buruk & 21 & $70 \%$ & 9 & $30 \%$ & 30 \\
\hline Jumlah & 28 & & 12 & & 40 \\
\hline
\end{tabular}

Tabel 11 Tabulasi silang faktor aktivitas fisik berdasarkan melakukan atau tidak melakukan di Puskesmas Pakis Surabaya Juni 2014

\begin{tabular}{|c|c|c|c|c|c|}
\hline \multirow{3}{*}{$\begin{array}{l}\text { Aktivit } \\
\text { as } \\
\text { fisik } \\
\text { Terken } \\
\text { dali }\end{array}$} & \multicolumn{5}{|c|}{ Aktivitas fisik } \\
\hline & \multicolumn{2}{|c|}{ Melakukan } & \multicolumn{2}{|c|}{$\begin{array}{l}\text { Tidak } \\
\text { Melakukan }\end{array}$} & \multirow{2}{*}{$\begin{array}{l}\text { Tot } \\
\text { Tot } \\
\text { al }\end{array}$} \\
\hline & $\begin{array}{l}\text { Juml } \\
\text { ah }\end{array}$ & $\begin{array}{l}\text { Prosenta } \\
\text { se }\end{array}$ & $\begin{array}{l}\mathrm{Ju} \\
\mathrm{mla} \\
\mathrm{h}\end{array}$ & $\begin{array}{l}\text { Prosen } \\
\text { tase }\end{array}$ & \\
\hline Baik & 2 & $40 \%$ & 3 & $60 \%$ & 5 \\
\hline Sedan & 4 & $80 \%$ & 1 & $20 \%$ & 5 \\
\hline $\begin{array}{l}\text { g } \\
\text { Buruk }\end{array}$ & 27 & $90 \%$ & 3 & $10 \%$ & 30 \\
\hline Jumlah & 33 & & 7 & & 40 \\
\hline
\end{tabular}


Tabel 12 Tabulasi silang faktor kepatuhan minum obat berdasarkan teratur atau tidak teratur di Puskesmas Pakis Surabaya Juni 2014

\begin{tabular}{llllll}
\hline $\begin{array}{l}\text { Kepatu } \\
\text { kan } \\
\text { minum } \\
\text { obdt }\end{array}$ & \multicolumn{3}{l}{ Kepatuhan Minum Obat } & \\
$\begin{array}{l}\text { Teratur } \\
\begin{array}{l}\text { Terken } \\
\text { dali }\end{array}\end{array}$ & $\begin{array}{l}\text { Juml } \\
\text { ah }\end{array}$ & $\begin{array}{l}\text { Prosent } \\
\text { ase }\end{array}$ & $\begin{array}{l}\text { Juml } \\
\text { ah }\end{array}$ & $\begin{array}{l}\text { Prosen } \\
\text { tase }\end{array}$ & $\begin{array}{l}\text { Tot } \\
\text { al }\end{array}$ \\
\hline Baik & 5 & $100 \%$ & - & - & 5 \\
Sedang & 5 & $100 \%$ & - & - & 5 \\
Buruk & 27 & $90 \%$ & 3 & $10 \%$ & 30 \\
Jumlah & 37 & & 3 & & 40 \\
\hline
\end{tabular}

Tabel 13 Tabulasi silang faktor pengetahuan berdasarkan baik, cukup atau kurang di Puskesmas Pakis Surabaya Juni 2014

\begin{tabular}{|c|c|c|c|c|c|c|c|}
\hline \multirow{3}{*}{$\begin{array}{l}\text { Peng } \\
\text { etah } \\
\text { uan } \\
\text { Terk } \\
\text { enda } \\
\text { li }\end{array}$} & \multicolumn{6}{|c|}{ Pengetahuan } & \multirow{3}{*}{$\begin{array}{l}\mathrm{T} \\
\text { ot } \\
\text { al }\end{array}$} \\
\hline & \multicolumn{2}{|c|}{ Baik } & \multicolumn{2}{|c|}{ Cukup } & \multicolumn{2}{|c|}{ Kurang } & \\
\hline & $\begin{array}{l}\mathrm{Ju} \\
\mathrm{ml} \\
\mathrm{ah}\end{array}$ & $\begin{array}{l}\text { Pros } \\
\text { enta } \\
\text { se }\end{array}$ & $\begin{array}{l}\mathrm{Ju} \\
\mathrm{ml} \\
\mathrm{ah}\end{array}$ & $\begin{array}{l}\text { Pros } \\
\text { enta } \\
\text { se }\end{array}$ & $\begin{array}{l}\mathrm{Ju} \\
\mathrm{ml} \\
\mathrm{ah}\end{array}$ & $\begin{array}{l}\text { Pro } \\
\text { sent } \\
\text { ase }\end{array}$ & \\
\hline Baik & 4 & $\begin{array}{l}80 \\
\%\end{array}$ & 1 & $\begin{array}{l}20 \\
\%\end{array}$ & - & - & 5 \\
\hline $\begin{array}{l}\text { Seda } \\
\text { ng }\end{array}$ & 2 & $\begin{array}{l}40 \\
\%\end{array}$ & 2 & $\begin{array}{l}40 \\
\%\end{array}$ & 1 & $\begin{array}{l}20 \\
\%\end{array}$ & 5 \\
\hline $\begin{array}{l}\text { Buru } \\
\mathrm{k}\end{array}$ & 7 & $\begin{array}{l}23,3 \\
\%\end{array}$ & 12 & $\begin{array}{l}40 \\
\%\end{array}$ & 11 & $\begin{array}{l}36 \\
7 \%\end{array}$ & 30 \\
\hline $\begin{array}{l}\text { Juml } \\
\text { ah }\end{array}$ & 13 & & 15 & & 12 & & 40 \\
\hline
\end{tabular}

\section{Pembahasan}

Berdasarkan tabel 10 menunjukkan bahwa diit tidak mempengaruhi terkendalinya kadar gula darah yaitu terkendalinya baik diit yang patuh sejumlah 3 orang $(60 \%)$ dan terkendali buruk diit yang patuh sejumlah 21 orang ( 70\%) . Menurut Waspadji ( 2007 ) Diabetesi harus dapat melakukan perubahan pola makan secara konsisten, salah satu manfaat pengaturan makan adalah untuk meningkatkan sensitifitas reseptor insulin sehingga akhirnya dapat menurunkan kadar glukosa darah. Apabila dilihat dari tabel 4.5 karakteristik responden berdasarkan faktor diit didapatkan yang patuh yaitu sebanyak 28 orang ( $70 \%$ ) hal ini menunjukkan antara teori dan fakta terdapat kesenjangan, karena perubahan pola makan dan pengaturan makan bukan satu-satunya faktor yang berpengaruh dan memegang peranan penting dalam melakukan pengendalian kadar gula darah pada pasien Diabetes Mellitus, melainkan masih banyak faktor lain yang mendukung untuk tercapainya status kesehatan yang optimal

( terkendalinya kadar gula darah ) bagi pasien diabetes, seperti: melakukan aktivitas atau olah raga yang rutin atau teratur. Dukungan keluarga juga sangat penting dalam pengendalian kadar gula darah pasien diabetes, misalnya: untuk melakukan olahraga teratur. Karena dengan adanya dukungan dari keluarga, pasien termotivasi untuk melakukan pengontrolan kadar gula darahnya.

Berdasarkan tabel 11 menunjukkan bahwa aktivitas fisik mempengaruhi terkendalinya kadar gula darah tetapi bertentangan yaitu terkendalinya baik aktivitas fisik yang melakukan sejumlah 2 orang ( $40 \%$ ) dan terkendali buruk aktivitas fisik yang melakukan sejumlah 27 orang ( $90 \%$ ) . Menurut Ilyasa dalam soegondo ( 2007 ) Latihan jasmani yang teratur menyebabkan kontraksi otot meningkat dan resistensi insulin berkurang. Apabila dilihat dari tabel 4.6 karakteristik responden berdasarkan faktor aktivitas fisik didapatkan yang melakukan yaitu sebanyak 33 orang ( $82,5 \%$ ) hal ini menunjukkan antara teori dan fakta tidak sama, sebagian besar orang yang kadar gula darahnya terkendali dengan baik justru tidak melakukan aktivitas fisik secara teratur karena kadar gula darah terkendali secara baik, juga dapat terjadi karena adanya kemauan dalam diri pasien untuk mengendalikan kadar gula darah, meskipun tidak hanya dengan aktivitas fisik atau olah raga. Responden yang kadar gula darahnya terkendali secara buruk justru melakukan aktivitas fisik secara teratur karena mereka mempunyai motivasi yang tinggi untuk melakukan usaha pengobatan dengan olahraga, aktivitas fisik secara teratur juga dapat menujukkan hasil positif dalam upaya pengobatan, seperti terkendalinya kadar gula darah pada pasien Diabetes Mellitus. Motivasi dan penghargaan baik diperlukan untuk dapat meningkatkan perilaku kesehatan, khususnya untuk pasien Diabetes Mellitus dalam mengendalikan kadar gula darah.

Berdasarkan tabel 12 menunjukkan bahwa kepatuhan minum obat tidak 
mempengaruhi terkendalinya kadar gula darah yaitu terkendalinya baik kepatuhan minum obat yang teratur sejumlah 5 orang $(100 \%)$ dan terkendali buruk kepatuhan minum obat yang teratur sejumlah 27 orang ( $90 \%$ ) . Menurut PERKENI ( 1998 ) Pada dasarnya pengelolaan Diabetes Mellitus tanpa dekompensasi metabolik dimulai dengan pengaturan makan, disertai dengan kegiatan jasmani yang cukup selama beberapa waktu. Bila setelah itu kadar glukosa darah masih belum dapat memenuhi kadar sasaran metabolik yang diinginkan, pasien diberikan obat hipoglikemi oral ( $\mathrm{OHO}$ ) atau suntikan insulin sesuai dengan indikasi. Apabila dilihat dari tabel 4.7 karakteristik responden berdasarkan faktor kepatuhan minum obat didapatkan yang teratur yaitu sebanyak 37 orang $(92,5 \%)$ hal ini menunjukkan antara teori dan fakta terdapat kesenjangan, karena pengendalian kadar gula darah pada pasien Diabetes Mellitus tidak hanya dengan mengkonsumsi obat antidiabetes ( OHO maupun insulin ) melainkan dengan melakukan aktivitas fisik yang rutin dan teratur juga dapat mengendalikan kadar gula darah. Faktor lama menderita penyakit Diabetes Mellitus, sehingga pasien merasa jenuh dan cenderung tidak mengkonsumsi obat antidiabetes sesuai instruksi.

Berdasarkan tabel 13 menunjukkan bahwa pengetahuan mempengaruhi terkendalinya kadar gula darah yaitu terkendalinya baik berpengetahuan baik sejumlah 4 orang ( $80 \%$ ) dan terkendali buruk berpengetahuan baik sejumlah 7 orang ( $23,5 \%)$ ). Menurut Winkle ( 1996 ) semakin cukup umur kematangan dan kekuatan seseorang akan lebih matang untuk bertindak. Apabila dilihat dari tabel 4.1 karakteristik responden berdasarkan usia didapatkan yang paling banyak yaitu berusia 4160 tahun yaitu sebanyak 30 orang ( $75 \%$ ) hal ini menunjukkan antara teori dan fakta terdapat kesamaan, semakin bertambahnya usia seseorang maka orang tersebut semakin mampu untuk berpikir dan mempersepsikan informasi yang didapat, sehingga ia akan berusaha untuk mematuhi segala sesuatu yang telah disampaikan untuk dilakukannya. Jika dilihat dari tingkat pendidikan berdasarkan tabel 4.3 karakteristik responden berdasarkan pendidikan didapatkan yang paling banyak yaitu 17 orang dengan tingkat pendidikan SMP. Menurut Nursalam ( 2001 ) semakin tinggi tingkat pendidikan seseorang maka semakin mudah orang tersebut menerima informasi, sehingga banyak pula pengetahuan yang dimiliki. Meskipun dengan tingkat pendidikan menengah memungkinkan seseorang memiliki pengetahuan yang baik karena informasi selain diperoleh dari pendidikan formal juga bisa diperoleh dari pendidikan non formal ataupun informasi yang didapat dari media massa maupun media elektronik.

\section{Kesimpulan}

Faktor diit tidak mempengaruhi terkendalinya kadar gula darah pada pasien Diabetes Mellitus di Puskesmas Pakis Surabaya.

Faktor aktivitas fisik mempengaruhi terkendalinya kadar gula darah pada pasien Diabetes Mellitus di Puskesmas Pakis Surabaya.

Faktor kepatuhan minum obat tidak mempengaruhi terkendalinya kadar gula darah pada pasien Diabetes Mellitus di Puskesmas Pakis Surabaya.

Faktor pengetahuan mempengaruhi terkendalinya kadar gula darah pada pasien Diabetes Mellitus di Puskesmas Pakis Surabaya.

\section{Daftar Pustaka}

Almatsier, Sunita. 2010. Penuntun Diet. Cet. 25. Jakarta : Kompas Gramedia

Arikunto, Suharsimi. 1998. Prosedur Penelitian. Jakarta : Rineka Cipta

Azwar, S. 1998. Metode Penelitian. Jakarta : EGC

Brunner and suddarth. 2000. Keperawatan Medikal Bedah. Jakarta : EGC

Fajri, Em dkk. 2000. Kamus Lengkap Bahasa Indonesia. Jakarta : EGC

Masyhuri \& Zainuddin, M. 2008. Metodologi Penelitian Pendekatan Praktis dan Aplikatif. Bandung

Notoatmodjo. 2008. Konsep dan Penerapan Metodologi Penelitian Ilmu Keperawatan Riset. Edisi 2. Jakarta : Salemba Medika

Notoatmodjo, S. 2003. Metodologi Penelitian Kesehatan. Jakarta : PT Rineka Cipta

Nursalam, Siti Pariani. 2001. Pendekatan Praktis Metodologi Riset Keperawatan. Jakarta : Salemba Medika

Nursalam, Soekidjo. 2005. Metodologi Penelitian Kesehatan. Jakarta : Rineka Cipta

Nursalam. 2003. Metode Riset Keperawatan. Jakarta : Salemba Medika

Pamela. J. Brink, Marylin J. Wood. Langkah Dasar Dalam Perencanaan Riset Keperawatan. Jakarta : EGC

Potter \& Perry. 2006. Buku Ajar Fundamental Keperawatan. Jakarta : EGC 
Pranandji, D, K. 2002. Perencanaan Menu Untuk Penderita Diabetes Mellitus. Jakarta : Penebar Swadaya

Setiadi. 2007. Konsep \& Penulisan Riset Keperawatan. Yogyakarta : Graha Ilmu

Soegondo dr sidartawan, dkk. 2000. Penatalaksanaan Diabetes Mellitus Terpadu. Jakarta : FKUI

Soewondo, P. 2002. Pemantauan Pengendalian Diabetes Mellitus; dalam Penatalaksanaan Diabetes Mellitus Terpadu. Jakarta : FKUI

Suyono, dkk. 2001. Buku Ajar Ilmu Penyakit Dalam. Jakarta : Balai Penerbit FKUI

Tjokroprawiro, Askandar. 2000. Diabetes Mellitus Klasifikasi, Diagnosa dan Terapi. Jakarta : Gramedia Pustaka Utama 